\title{
A NOVEL TECHNIQUE FOR COMMERCIAL MASS PRODUCTION OF NATURAL ENEMIES
}

\author{
GAFFAR, S. ${ }^{1}$, M. E. EL-NAGGAR ${ }^{2}$ and W. Z. A. MIKHAIL ${ }^{3}$ \\ 1. Central Laboratory of Organic Agriculture, ARC, Giza, Egypt. \\ 2. Plant Protection Research Institute, ARC, Giza, Egypt. \\ 3. Dep. Natural Resources, Inst. African Research \&studies, Cairo Univ., 12613 Giza, \\ Egypt. \\ ${ }^{1}$ Saad_bio_organic@yahoo.com \\ (Manuscript received 13 February 2012)
}

\begin{abstract}
Biological control agents is considered as an important factor of IPM strategy, efforts have been and are still being made to evaluate the effects of residual insecticides on natural enemy population. The commercial production of predators and parasitoids, using factitious hosts, such as, the Angoumois Grain Moth (AGM), Sitotroga cerealella (Olivier), the Mediterranean Flour Moth (MFM), Ephestia kuehniella Zeller and the Rice moth (RM), Corcyra cephalonica (Stainton) proved successful approach. This study involved, technical improvement for egg laying, collecting the eggs and testing of different collection techniques, manual and automatic rotation cylinders were studied. The main finding indicated that, the total eggs laying during 55 days from 21 trays containing Sitotroga adults reached $478.072 \mathrm{~g}$ in case of the mechanical cardboard, while it introduced $289.46 \mathrm{~g}$ in case of the manual rotation. Moreover, the patent no. of 2005020071 under the title " Egg laying collecting machine for the hosts of mass production" was obtained during this work modified machine for egg laying and collection for the mass production of insect host.
\end{abstract}

Key Words: IPM, factitious, biological, residual, predators, parasitoids.

\section{INTRODUCTION}

Sitotroga cerealella (Olivier) (AGM) eggs are widely used in the countries of the Former Soviet Union, Eastern Europe, North and South America and Egypt. During the last twenty years considerable knowledge and experience in the production of factitious host eggs for use in mass rearing of natural enemies has accumulated. Egg laying and collecting machine for the hosts of mass production has taken several steps by several investigators, i.e. Daumal et al. 1975; Grimm \& Lawrence, 1975; Hassan, 1981; Greenberg et al., 1998; Soeb, 2000 and El-Arnaouty, 2001. From 2002 until 2005, designed and manufactured cardboard for egg laying and collecting for mass production and remove the moth wing scales automatically in the same time 
were obtained . Finally, the goal was achieved by the patent no. 2005020071 (Gaffar, $2006 \& 2007)$.

The goal of this study was to solve the methodological problems for the production of these factitious hosts.

\section{MATERIALS AND METHODS}

The machine dimensions were $210 \mathrm{~cm}$ highest; $70 \mathrm{~cm}$ width and $90 \mathrm{~cm}$ depth and the whole machine was made from stainless steel $4 \times 4 \mathrm{~cm}$ and consist of two groups and lower each group drawer (no. 5) for egg collection with dimension $(80 \mathrm{~cm}$ width $\times 16 \mathrm{~cm}$ length $\times 80 \mathrm{~cm}$ depth) made from plastic and in the base of drawer a hole for egg collection. Also, two plastic plates $(15 \times 80 \mathrm{~cm})$ were used for determine the direction of eggs which will drop from cylinder for collecting in the middle of drawer (no. 9). Each group contained 5 cylinders, the dimension of each cylinder (54 $\times 17 \times 1.5 \mathrm{~cm}$ ) coated with mesh 28 (no. 7), the holes of mesh suitable to move moths eggs through it and not allowing the moths to come out. Each group contain an iron door $(4 \times 4 \mathrm{~cm})$ coated with plastic. Each group consists of two plastic circles ( $1 \mathrm{~cm}$ thickness $\times 50 \mathrm{~cm}$ diameter), a iron rod of stainless steel was connected with the two plastic circles ( $21 \mathrm{~cm}$ diameter) it was fixing on the rod (no. 8), where one in the front and other one from the back that was fixed on stainless $(4 \times 4 \mathrm{~cm})$, also the plastic plate was fixed on the stainless rod by the cubic part of aluminum (holder of plastic sheet) (no. 4). The cleaning cylinder brush will be fixed between the two plastic sheets, it attained the place of brush should be at the reversed of cylinder moving with dimension ( $48 \times 2 \times 5 \mathrm{~cm}$ ) (no. 10)to prevent fall the eggs on it. In the end of the stainless rod fixed a part of iron (30 cm dimension) was made from aluminum (no. 11) it was connected with the lower movement group (30 cm dimension) (no. 13). The lower and upper groups would be connected together by leather belt No. 106A (no. 12). This lower iron plate connecting with another small iron plate to transfer the movement with two channels (18 and $7 \mathrm{~cm}$ ) (no. 14). To reduce the speed by leather belt No. $64 \mathrm{~A}$ this iron plate could be fixed by two rolling iron fixed on two iron rods to pull the leather belt in addition to reduce the speed. This iron plate was connected with motor (no. 15) with other leather belt No. 43A. The motor connecting with gearbox (100 Watt and power 2000 rotation/min., $50 \mathrm{HZ}$, $220 \mathrm{~V}, 3 \mu \mathrm{F}$ ) (Fig. 1).

The present investigation aim to compare between mechanical and manual cardboard. In this trial, this eggs were collected from the mass production source. Two cardboard from rearing of $S$. cerealella moth were used, each one contains 21 
trays, each tray contains $6 \mathrm{~kg}$ wheat infested by $6 \mathrm{~g}$ wheat infested by $6 \mathrm{~cm} S$. cerealella eggs (Hassan et al. 1978; Hassan, 1981 \& 1994). The eggs were taken daily and divided in the two cardboard and the obtained eggs were weighed daily for 55 days by AND (scale: $0.01 \mathrm{mg}$ to $42 \mathrm{~g}$ ).

Results were recorded and statistically analyzed using ANOVA statistical method analyzed with variance for detecting significance between the treatments by using Duncan's multiple range test (1955) to compare efficacy between treatments, and by T-test to compare the daily production of prey mechanical and manual cardboard.

\section{RESULTS AND DISCUSSION}

\section{The movement of machine}

\subsection{Main movement}

This movement is carried out by the back movement group (iron plates and leather belts). Each group will be done with all components (cylinders with alternative host moths); the cylinder works by two iron parts (no. 2). This is a cubic part made of aluminum ( $5 \mathrm{~cm}$ diameter) this diameter similar the hole diameter in plastic sheet, with $1 \mathrm{~cm}$ width and the middle of iron plate its round itself in all directions.

\subsection{Terminal movement}

Meaning the cylinder rotation is cleaning itself from eggs which attacking in mesh of the cylinder by brush, this rotation was occurring by leather belt. In addition, aspirator found for removing insect scales from the machine and from the eggs (no. 6), connecting to the machine a plastic tube with 2 inch diameter to obtain the cleaning host eggs adopted for laying the parasite its eggs in it and mass production of Trichogramma, in addition safe to the environment to be free from pollution and safe to the workers health. The machine is working daily for only 1 hour (4 rounds), the motor gave 20 rotations/min., and because the movement of cylinder around itself could be utilized very slowly, this will be useful for machine age and to obtain good eggs useful for mass rearing of Trichogramma parasitoids. The second steps of trays were maintained till about emergence, according to the previously described protocol. The emerging adults were collected daily throughout 55 day and the production daily of adults from the first set will put in the automatic system and another set can put in the manual system. Moreover, the produced eggs by the adults were considered as regard to the cumulative production. 


\section{The advantages in this procedure are}

1. This machine with dimensions $210 \mathrm{~cm}$ highest $\times 90 \mathrm{~cm}$ width $\times 70 \mathrm{~cm}$ depth, the machine became wide vertically to put a lot of cylinders, can be put from $10-12$ cylinders in two levels.

2. The machine was manufactured from hard iron $4 \times 4$ as a fundamentals and was built on it the all parts, which made of plastic and aluminum to changed easily.

3. Easy to distribute the brushes, which are important for cleaning the cylinders and to easily daily working.

4. To reduce the effort and time for works by easily machine working without any noise sound.

5. Movement on leather belts and iron plates, lead to avoid a nosy sound, and put timer as well as to reduce the cost of price.

6. Fixing air flow system to reduce egg contamination with insect scales, and the machine is closing carefully by the plastic doors.

7. Dropped the eggs directly in the drawer without damage and lead to be collected easily.

8. The machine could be cleaned easily.

9. The machine connecting with gearbox to control and reduce the speed.

10. Fixing an iron pole covered with leather belt, this lead the cylinder to round on itself to reduce the motor speed and increasing the cylinder speed by gearbox.

11. The connection between the motor and iron pole leads to the leather belt to obtain good fixing.

12. The cylinder move easy on itself on the leather belt and regularly.

13. The whole machine could be moved regularly.

14. A lot of cylinders can be obtained by increase the height of machine (60 cylinders in a machine).

\section{Daily productions of prey eggs of manual cardboard}

Data in Table (1) demonstrated that, the cumulative egg production (289.46 g) was observed in this treatment. The daily egg production reached $5.263 \pm 4.544$.

\section{Daily productions of prey eggs of mechanical cardboard}

Results in Table (2) indicated that the cumulative egg production attained 478.72 g. The daily egg production reached $8.704 \pm 6.758$. 
Statistical analysis in Table (3) showed significant difference between power and manual cardboard for collection eggs of alternative host under optimal conditions for rearing (L.S.D at 5\% 2.18).

Data in Tables $(1,2 \& 3)$ indicated that the total eggs laid during 55 day from 21 tray reached $478.072 \mathrm{~g}$ and the daily average reached 8.704 in case of the mechanical cardboard, while the production of each tray reached $22.765 \mathrm{~g}$ during the same time. In other word, $6 \mathrm{~g}$ which beginning infestation/tray gave $22.765 \mathrm{~g}$ as a production from the eggs meaning each gram gave $3.8 \mathrm{~g}$ as a production.

Also, data indicated that the total eggs laid during 55 day from 21 tray reached $289.46 \mathrm{~g}$ and the daily average reached 5.263 in case of the manual cardboard, while the production of each tray recorded $13.784 \mathrm{~g}$ during the same time. In other words 6 $\mathrm{g}$ which beginning infestation/tray gave $13.784 \mathrm{~g}$ as a production from the eggs meaning each gram gave $2.297 \mathrm{~g}$ as a production. 

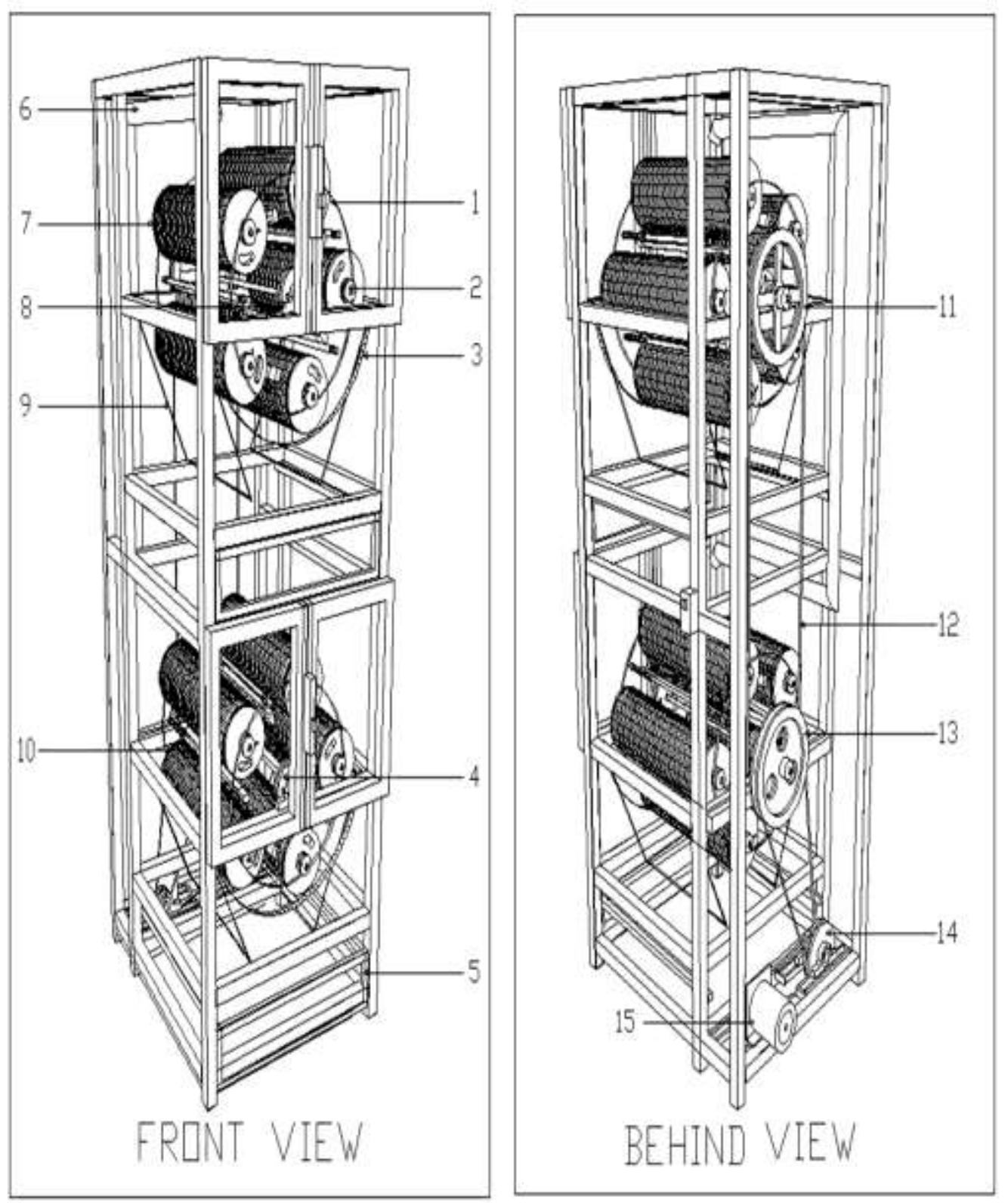

Fig. 1. Egg laying and collecting machine for the hosts of mass production. 
Table 1. Egg production obtained by manual cardboard.

\begin{tabular}{|c|c|c|c|}
\hline Day & Egg weight (g)/ day & Day & Egg weight (g)/ day \\
\hline 1 & 0.3 & 29 & 12.43 \\
\hline 2 & 0.7 & 30 & 9.33 \\
\hline 3 & 0.26 & 31 & 8.17 \\
\hline 4 & 0.32 & 32 & 8.61 \\
\hline 5 & 1.58 & 33 & 12.37 \\
\hline 6 & 0.26 & 34 & 6.63 \\
\hline 7 & 0.63 & 35 & 10.26 \\
\hline 8 & 0.95 & 36 & 10.62 \\
\hline 9 & 1.61 & 37 & 8.15 \\
\hline 10 & 1.47 & 38 & 8.59 \\
\hline 11 & 3.36 & 39 & 13.98 \\
\hline 12 & 1.82 & 40 & 3.94 \\
\hline 13 & 2.82 & 41 & 0.98 \\
\hline 14 & 4.98 & 42 & 2.19 \\
\hline 15 & 9.04 & 43 & 2.19 \\
\hline 16 & 4.67 & 44 & 1.97 \\
\hline 17 & 5.23 & 45 & 1.15 \\
\hline 18 & 5.28 & 46 & 1.57 \\
\hline 19 & 6.70 & 47 & 1.23 \\
\hline 20 & 8.02 & 48 & 1.61 \\
\hline 21 & 11.45 & 49 & 1.41 \\
\hline 22 & 11.31 & 50 & 1.34 \\
\hline 23 & 13.29 & 51 & 1.36 \\
\hline 24 & 8.73 & 52 & 1.40 \\
\hline 25 & 14.16 & 53 & 1.56 \\
\hline 26 & 12.39 & 54 & 1.42 \\
\hline 27 & 12.68 & 55 & 1.12 \\
\hline 28 & 10.14 & & \\
\hline$\Sigma x$ & \multicolumn{3}{|l|}{289.46} \\
\hline Mean & \multicolumn{3}{|l|}{5.263} \\
\hline S.D & \multicolumn{3}{|l|}{4.544} \\
\hline
\end{tabular}


Table 2. Egg production obtained by mechanical cardboard.

\begin{tabular}{|c|c|c|c|}
\hline Day & Egg weight (g)/ day & Day & Egg weight (g)/ day \\
\hline 1 & 0.7 & 29 & 12.30 \\
\hline 2 & 0.5 & 30 & 18.86 \\
\hline 3 & 1.58 & 31 & 8.58 \\
\hline 4 & 0.68 & 32 & 16.94 \\
\hline 5 & 0.81 & 33 & 11.61 \\
\hline 6 & 1.86 & 34 & 11.94 \\
\hline 7 & 1.32 & 35 & 9.16 \\
\hline 8 & 1.26 & 36 & 11.51 \\
\hline 9 & 2.78 & 37 & 10.51 \\
\hline 10 & 2.36 & 38 & 18.96 \\
\hline 11 & 3.86 & 39 & 14.75 \\
\hline 12 & 7.37 & 40 & 2.11 \\
\hline 13 & 10.28 & 41 & 1.07 \\
\hline 14 & 15.29 & 42 & 2.59 \\
\hline 15 & 16.81 & 43 & 3.56 \\
\hline 16 & 11.34 & 44 & 6.59 \\
\hline 17 & 14.58 & 45 & 1.63 \\
\hline 18 & 9.77 & 46 & 4.25 \\
\hline 19 & 16.22 & 47 & 6.16 \\
\hline 20 & 18.04 & 48 & 6.03 \\
\hline 21 & 16.17 & 49 & 4.34 \\
\hline 22 & 17.94 & 50 & 3.30 \\
\hline 23 & 19.88 & 51 & 1.36 \\
\hline 24 & 22.39 & 52 & 3.30 \\
\hline 25 & 15.28 & 53 & 4.20 \\
\hline 26 & 19.76 & 54 & 2.43 \\
\hline 27 & 17.25 & 55 & 1.13 \\
\hline 28 & 14.55 & & \\
\hline$\Sigma x$ & \multicolumn{3}{|l|}{478.72} \\
\hline Mean & \multicolumn{3}{|l|}{8.704} \\
\hline S.D & \multicolumn{3}{|l|}{6.758} \\
\hline
\end{tabular}


Table 3. Comparison between the mean daily production of prey eggs of mechanical and the manual cardboard from mass rearing of factitious host, $S$. cerealella.

\begin{tabular}{|l|c|c|}
\hline \multicolumn{1}{|c|}{ Parameter } & Power system & Manual system \\
\hline Mean daily of egg production/day & $\mathbf{8 . 7 0 4}^{\mathrm{a}}$ & $\mathbf{5 . 2 6 3 ^ { \mathrm { b } }}$ \\
\hline L.S.D at $5 \%$ & \multicolumn{2}{|c|}{$\mathbf{2 . 1 8}$} \\
\hline
\end{tabular}

\section{REFERENCES}

1. United production massive quotidienne d'un hôte substitution Ephestia kuehniella Zeller (Lep.: Pyralidae). Annales de zoologie, Ecologic Animales, 7: 45-49.

2. Duncan, D. B. 1955. Multiple range and multiple F-test. Biometrics, 11:1-42.

3. El-Arnaouty, S. A. 2001. Technical improvements in mass rearing of Ephestia kuehniella Zeller (Lep.: Pyralidae) as a substitution prey for a cost effective production of Crysoperla carnea Steph. Integrated Pest Management, Proc. Of the $1^{\text {st }}$ Congress, Cairo Univ., Fac. Agric., 22-23 April, Part I, 42-52.

4. Gaffar, S. 2006. Some factors affecting parasites on potential of some Trichogramma parasitoid species under mass rearing conditions in Egypt and Tunisia. M. Sc. Thesis, Institute of African Research and Studies. Cairo Univ., 145 pp.

5. Gaffar, S. 2007. Egg laying and collecting machine for the hosts of mass production. Patent applications No. 2005020071. Patent Gazette, Ministry of Scientific Research, Academy of Scientific Research and Technology, February 2007, 666: 6 P.

6. Greenberg, S. M., P. K., Morrison, D. A., Nadlund, and E. G. King. 1998. A review of scientific literature and methods for production of factitious hosts for use in mass rearing of Trichogramma spp. (Hym.: Trichogrammatidae) in the former Soviet Union, the United States, Western Europe and Chine. J. Entomol. Sci., 33(1): 15-32.

7. Grimm, M. and P. J. T. Lawrence. 1975. Biological control of insects on the Ord. 1. Production of Sitotroga cerealella for mass rearing of Trichogramma wasps. J. Agric. Dept. Agric. Western Australia, 90-92.

8. Hassan, S. A. 1981. Mass production and utilization of Trichogramma: 1. Production of the host S. cerealella. Entomophaga, 26(4): 339-348. 
9. Hassan, S. A. 1994. Improved method for the production of the Angoumois grain moth, S. cerealella. (Oliv.), pp.157-160. In E. Wajenberg (ed.),. "Trichogramma and other egg parasitoids" Proc. of $4^{\text {th }}$ International Symposium, Cairo, Egypt, 4-7 October 1994, Les Colloques de L,INRA, 73:95-99.

10. Hassan, S. A., G. A. Langenbruch and G., Neuffer. 1978. Influence of the host in the mass rearing of the effectiveness of the egg parasite, Trichogramma evanescens to the European corn borer, Ostrinia nubilalis. Entomophaga, 23(4): 321-329.

11. Soeb, M. A. 2000. Factors affecting the mass production of Trichogramma buesi Voegelé (Hym.: Trichogrammatidae). Ph.D. Thesis, Fac. Agric. Cairo Univ., 133 pp. 


\section{تكنيك جديد للإنتاج الكمي التجاري للآعداء الطبيعية}

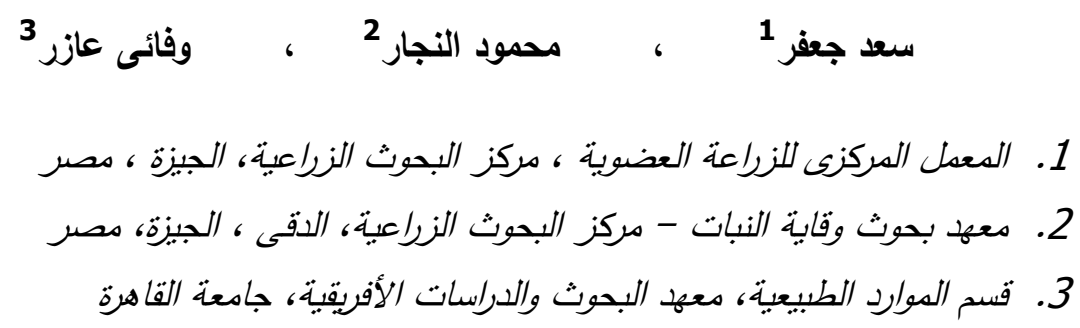

تعتبر المكافحة الحيوية جزء من إستراتيجية الإدارة المتكاملة للآفات. فقد بذلت الجهود وما زالت لتقييم التأثير السام لمتنقيات المبيدات الحشرية على الآعداء الحيوية. تنتخدم العوائل الطبيعية البديلة

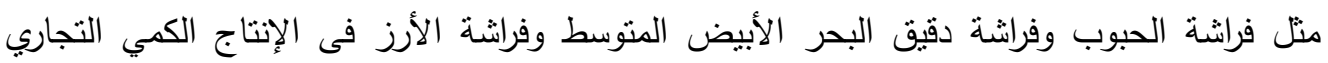

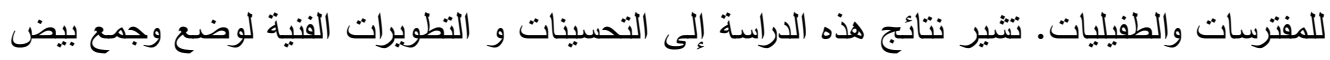
العوائل البديلة و أيضاً اختبار تقنيات الجمع المختلفة منل الأسطوانات الدوارة اليدوية والأوتوماتيكية. تشير الحقائق إلى أن اجمالى البيض الذي وضعته إناث فرانة الحبوب خلال 55 يوم من 21 برواز

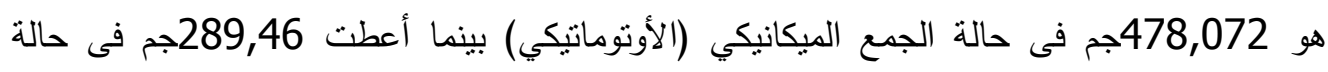
الجمع اليدوي. علاوة على ذللك تم تحسين ماكينة لوضع وجمع بيض العائل البديل للإنتاج الكمي ونم الحصول على براءة اختراع رقم 2005020071 تحت عنوان " ماكينة وضع وجمع بيض العائل

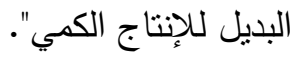

